\title{
Impacts of elicitors on metabolite production and on antioxidant potential and tyrosinase inhibition in watercress microshoot cultures
}

\author{
Marta Klimek-Szczykutowicz ${ }^{1,2} \cdot$ Michał Dziurka $^{3} \cdot$ Ivica Blažević ${ }^{4} \cdot$ Azra Đulović $^{4} \cdot$ Anna Apola $^{5} \cdot$ Halina Ekiert $^{1}$. \\ Agnieszka Szopa' ${ }^{1}$
}

Received: 19 May 2021 / Revised: 6 December 2021 / Accepted: 11 December 2021 / Published online: 5 January 2022

(c) The Author(s) 2022, corrected publication 2022

\begin{abstract}
The study has proved the stimulating effects of different strategies of treatments with elicitors on the production of glucosinolates (GSLs), flavonoids, polyphenols, saccharides, and photosynthetic pigments in watercress (Nasturtium officinale) microshoot cultures. The study also assessed antioxidant and anti-melanin activities. The following elicitors were tested: ethephon (ETH), methyl jasmonate (MeJA), sodium salicylate (NaSA), and yeast extract (YeE) and were added on day 10 of the growth period. Cultures not treated with the elicitor were used as control. The total GSL content estimations and UHPLC-DAD-MS/MS analyses showed that elicitation influenced the qualitative and quantitative profiles of GSLs. MeJA stimulated the production of gluconasturtiin $(68.34 \mathrm{mg} / 100 \mathrm{~g}$ dried weight $(\mathrm{DW}))$ and glucobrassicin $(65.95 \mathrm{mg} / 100 \mathrm{~g} \mathrm{DW})$. The elicitation also increased flavonoid accumulation (max. $1131.33 \mathrm{mg} / 100 \mathrm{~g} \mathrm{DW}$, for $100 \mu \mathrm{M}$ NaSA, collection after $24 \mathrm{~h}$ ). The elicitors did not boost the total polyphenol content. NaSA at $100 \mu \mathrm{M}$ increased the production of total chlorophyll $a$ and $b$ (5.7 times after $24 \mathrm{~h}$ of treatment), and $50 \mu \mathrm{M}$ NaSA caused a 6.5 times higher production of carotenoids after 8 days of treatment. The antioxidant potential (assessed with the CUPRAC FRAP and DPPH assays) increased most after $24 \mathrm{~h}$ of treatment with $100 \mu \mathrm{M}$ MeJA. The assessment of anti-melanin activities showed that the microshoot extracts were able to cause inhibition of tyrosinase (max. $27.84 \%$ for $1250 \mu \mathrm{g} / \mathrm{mL}$ ).
\end{abstract}

\section{Key points}

- Elicitation stimulated of the metabolite production in N. officinale microshoots.

- High production of pro-health glucosinolates and polyphenols was obtained.

- N. officinale microshoots have got tyrosinase inhibition potential.

- The antioxidant potential of $N$. officinale microshoots was evaluated.

Keywords Nasturtium officinale $\cdot$ In vitro cultures $\cdot$ Elicitation · Glucosinolates · Polyphenols · Antioxidant potential · Tyrosinase inhibition

Agnieszka Szopa

a.szopa@uj.edu.pl

Marta Klimek-Szczykutowicz

marta.klimek-szczykutowicz@ doctoral.uj.edu.pl

Michał Dziurka

m.dziurka@ifr-pan.edu.pl

Ivica Blažević

blazevic@ktf-split.hr

Azra Đulović

azra@ktf-split.hr

Anna Apola

anna.apola@uj.edu.pl

Halina Ekiert

halina.ekiert@uj.edu.pl
1 Chair and Department of Pharmaceutical Botany, Faculty of Pharmacy, Jagiellonian University, Medical College, Medyczna 9, 30-688 Kraków, Poland

2 Department of Dermatology, Cosmetology and Aesthetic Surgery, The Institute of Medical Sciences, Medical College, Jan Kochanowski University, Stefana Żeromskiego 5, 25-369 Kielce, Poland

3 The Franciszek Górski Institute of Plant Physiology, Polish Academy of Sciences, Niezapominajek 21, 30-239 Kraków, Poland

4 Department of Organic Chemistry, Faculty of Chemistry and Technology University of Split, Ruđera Boškovića 35, 21000 Split, Croatia

5 Department of Inorganic Chemistry, Faculty of Pharmacy, Jagiellonian University Medical College, Medyczna 9, 30-688 Kraków, Poland 


\section{Introduction}

Nasturtium officinale $\mathrm{R}$. Br., known as watercress, is a perennial, aquatic, or semiaquatic plant species. It grows mainly in wetlands, near streams and running water. $N$. officinale is a widely commercially cultivated species, recently mainly as source of "super food" or "fit food," due to its low calorific value $(11 \mathrm{cal}$ in $100 \mathrm{~g}$ of FW (fresh weight)), and a rich source of valuable compounds such as glucosinolates (GSLs), polyphenols, vitamins (B1, B2, B3, B6, E, C), and bioelements (Afsharypuor and Salehi 2008; Martínez-Sánchez et al. 2008; Boligon et al. 2013; Jeon et al. 2017). It is a leafy vegetable, often grown in hydroponic cultures and in gravel beds with a constant flow of water passing through them. It has a short cultivation time. The cultivation takes from 4 to 8 weeks from transplanted seedling to harvest (Lira et al. 2018; De Lira et al. 2019). The European Food Safety Authority (EFSA) has classified $N$. officinale as a safe vegetable under the group "Leaf vegetables, herbs and edible flowers" (EFSA). Currently, it is becoming one of the most important plants used in healthy food and modern cuisine. $N$. officinale is increasingly being used in European, Brazilian, and North American cuisine. It is commonly used as salad, but also garnish for meats and other dishes where a peppery or pungent flavor is desired (Palaniswamy and McAvoy 2001). Interest in $N$. officinale as a salad vegetable for health promotion and disease prevention has increased due to numerous studies confirming that isothiocyanates in this species reduce the risk of cancer (De Souza et al. 2016; Li et al. 2016; Yuan et al. 2016). Isothiocyanates are compounds formed by the hydrolysis of GSLs via myrosinase (Palaniswamy and McAvoy 2001). The conducted studies have also shown that, apart from anticancer activity, extracts of $N$. officinale also have antioxidant, antibacterial, and antiinflammatory properties (Holst and Williamson 2004; Bahramikia and Yazdanparast 2010; Sadeghi et al. 2014; Li et al. 2016).

Plant biotechnology gives possibilities to cultivate rare and protected plants regardless of climatic conditions, with biomass being available all year round. Plant in vitro cultures can be used to stimulate production of valuable secondary metabolites by the influence of various factors on cultures. Finally, they can be cultivated on an industrial scale by being grown in bioreactors (Karuppusamy 2009).

The production of secondary metabolites in plant in vitro cultures can be stimulated by different treatments with elicitors. Elicitation is one of the most promising methods used in plant biotechnology to enhance productivity by stress induction. It involves manipulation of metabolite and biochemical pathways. In plant physiology, "stress" is defined by a factor (biotic or abiotic) which can modify plant growth, reproduction, and functioning.
Abiotic elicitors have non-biological sources, which could include both physical agents (e.g., ultraviolet irradiation, temperature, mechanical wounding) and chemical substances, such as salicylic acid (SA), jasmonic acid (JA), and methyl jasmonate (MeJA). Biotic elicitors have a biological origin, i.e., they come from a microbial or plant source, such as yeast extract (YeE). Adding elicitors exogenously to culture media generally causes stimulation of secondary metabolite production under in vitro conditions (Narayani and Srivastava 2017). Studies have shown an increase of the production of oleanolic acid in cell suspension cultures of Calendula officinalis after treatments with JA (Wiktorowska et al. 2010). MeJA has been found to induce higher accumulation of resveratrol in cell suspension cultures of Vitis vinifera (Santamaria et al. 2012), gymnemic acid in cell suspension cultures of Gymnema sylvestre (Chodisetti et al. 2015), ginsenosides in cell suspension cultures of Panax ginseng (Thanh et al. 2005), and rosmarinic acid in cell suspension cultures of Mentha piperita (Krzyzanowska et al. 2012). There have been scientific studies which also confirmed the stimulating effect of SA on the production of phenolic acids in cell cultures of Salvia miltiorrhiza (Dong et al. 2010) and jaceosidin and syringin in cell suspension cultures of Saussurea medusa (Yu et al. 2006). Ethephon (ETH) has been demonstrated to stimulate the production of anthocyanins in hairy root cultures of Daucus carota ssp. sativus var. atrorubens (Barba-Espín et al. 2020) and pseudohypericin in Hypericum perforatum shoot cultures (Rao et al. 2010). Studies with YeE have confirmed enhanced production of dibenzocyclooctadiene lignans in Schisandra chinensis microshoot cultures (Szopa et al. 2018).

The aim of the present research was to evaluate the influence of treatments with different elicitors: ETH, MeJA, sodium salicylate ( $\mathrm{NaSA}$ ), and YeE, on stimulating the production of GSLs, flavonoids, and polyphenols in the $N$. officinale microshoot in vitro culture model. The influence of the applied elicitation strategies were also assessed in respect of the production of primary metabolites. This study were estimated total soluble saccharides and photosynthetic pigments. Moreover, the antioxidant potential and anti-melanin properties of extracts from $N$. officinale microshoots cultured in vitro were evaluated.

\section{Materials and methods}

\section{Experimental in vitro cultures}

Initial microshoot cultures of $N$. officinale were established and maintained as reported previously (Klimek-Szczykutowicz et al. 2019). This study involved cultivating $N$. officinale microshoots in $300 \mathrm{~mL}$ Erlenmeyer flasks containing 
$100 \mathrm{~mL}$ of Murashige and Skoog (MS) medium (Murashige and Skoog 1962) with 3\% (w/v) sucrose and supplemented with $1 \mathrm{mg} / \mathrm{L}$ 6-benzyladenine (BA) and $1 \mathrm{mg} / \mathrm{L} 1$-naphthaleneacetic acid (NAA). The medium composition was identified in our previous research as optimal for the cultivation of microshoots (Klimek-Szczykutowicz et al. 2020b). The inoculum used in this study was composed of $1 \mathrm{~g}$ of FW of $N$. officinale microshoots. The cultures were grown on a rotary shaker (Altel, Cracow, Poland) at $140 \mathrm{rpm}$. The microshoots were grown under continuous exposure to a light-emitting diode (LED) white light $\left(2.75 \mathrm{~W} / \mathrm{m}^{2}\right)$ at a temperature of $25 \pm 2^{\circ} \mathrm{C}$. All the experiments involved three series of cultures $(n=6)$.

\section{Elicitation procedure}

Sterile stock solutions of elicitors were added to the experimental cultures on day 10 of the growth period. The culture media contained the following concentrations of elicitors: 25 and $50 \mu \mathrm{M}$ ETH (Sigma-Aldrich, St. Louis, MO, USA), 50 and $100 \mu \mathrm{M}$ MeJA (Sigma-Aldrich, St. Louis, MO, USA), 50 and $100 \mu \mathrm{M}$ NaSA (POCH, SA, Gliwice, Poland), and $1 \mathrm{mg} / \mathrm{mL}$ and $3 \mathrm{mg} / \mathrm{mL}$ YeE (Sigma-Aldrich, St. Louis, MO, USA). The experimental media and biomass samples were collected $24 \mathrm{~h}, 48 \mathrm{~h}$, and 4, 6, and 8 days after treatments with the elicitors.

A stock solution of ETH was prepared by dissolving $4.16 \mathrm{mg}$ in $55 \mathrm{~mL}$ distilled $\mathrm{H}_{2} \mathrm{O}$ for the concentration of $25 \mu \mathrm{M}$ and $8.34 \mathrm{mg}$ in $55 \mathrm{~mL}$ for $50 \mu \mathrm{M}$. The solution was filter-sterilized using a $0.22 \mu \mathrm{m}$ syringe filter (Millex ${ }^{\circledR} \mathrm{GP}$; Merck Millipore, Burlington, MA, USA), and $5 \mathrm{~mL}$ was added to the culture medium to obtain proper concentration in the medium.

MeJA was prepared by dissolving $12.95 \mu \mathrm{L}$ in $5 \mathrm{~mL}$ of $96 \%$ ethanol for the concentration of $50 \mu \mathrm{M}$ and $25.90 \mathrm{mg}$ in $5 \mathrm{~mL}$ of $96 \%$ ethanol for $100 \mu \mathrm{M}$. Further dilution was made with distilled $\mathrm{H}_{2} \mathrm{O}$ to $55 \mathrm{~mL}$. The solution was filtersterilized using a $0.22 \mu \mathrm{m}$ syringe filter (Millex ${ }^{\circledR} \mathrm{GP}$; Merck Millipore, Burlington, MA, USA), and $5 \mathrm{~mL}$ was added to the culture medium to obtain proper concentration in the medium.

A stock solution of NaSA was prepared by dissolving $9.24 \mathrm{mg}$ in $55 \mathrm{~mL}$ distilled $\mathrm{H}_{2} \mathrm{O}$ for the concentration of $50 \mu \mathrm{M}$ and $18.48 \mathrm{mg}$ in $55 \mathrm{~mL}$ for $100 \mu \mathrm{M}$. The solution was filter-sterilized using a $0.22 \mu \mathrm{m}$ syringe filter (Millex ${ }^{\circledR} \mathrm{GP}$; Merck Millipore, Burlington, MA, USA), and $5 \mathrm{~mL}$ was added to the culture medium to obtain proper concentration in the medium.

YeE was prepared according to the method of Peltonen et al. (1997). YeE amounts of 1.155 and $3.465 \mathrm{~g}$ were diluted in $55 \mathrm{~mL}$ distilled $\mathrm{H}_{2} \mathrm{O}$, autoclaved, and added to the culture medium to obtain the concentrations of 1 and $3 \mathrm{mg} / \mathrm{mL}$.
Microshoots which were grown without elicitors were established as control (C), and on day 10 of the growth period, redistilled sterile $\mathrm{H}_{2} \mathrm{O}$ was added to the flask in the amount corresponding to that used to dissolve the elicitors $(5 \mathrm{~mL})$. The control samples were collected at the same time points as those of the experimental cultures.

\section{Calculation of the growth index}

Biomass increments were calculated using the growth index (Gi). Microshoots were collected 24 h, 48 h, and 4, 6, and 8 days after the addition of elicitors, lyophilized (freeze dryer, Labconco Corporation, Kansas City, MO, USA), and dried weight (DW) was weighed. The Gi was calculated using the formula: $\mathrm{Gi}=\frac{\left(\mathrm{Dw}_{1}-\mathrm{Dw}_{0}\right)}{\mathrm{Dw}_{0}}$, where $\mathrm{Dw}_{1}$ is the dry weight of microshoots at the end of the experiment, and $\mathrm{Dw}_{0}$ is the dry weight of the inoculum (Grzegorczyk and Wysokińska 2008).

\section{Sample preparation}

Plant material harvested from the tested $N$. officinale microshoot cultures was immediately frozen in liquid $\mathrm{N}_{2}$ and lyophilized (freeze dryer, Labconco Corporation, Kansas City, MO, USA). The dry biomass was pulverized (MM400, Retch, Haan, Germany). Samples (0.2 g) were weighed out and extracted twice with $4 \mathrm{~mL}$ of methanol (STANLAB, Lublin, Poland) under sonication for $20 \mathrm{~min}$ (ultrasonic bath; POLSONIC 2, Warsaw, Poland). Then, the samples were centrifuged $(7 \mathrm{~min}, 2000 \times \mathrm{g}$; MPW-223E centrifuge; MPW, Warsaw, Poland) and filtered $(0.22 \mu \mathrm{m}$ syringe filters; Millex ${ }^{\circledR} \mathrm{GP}$; Merck Millipore, Burlington, MA, USA). If not otherwise stated, these extracts were used for further analyses.

\section{Spectrophotometric analysis of the total GSL pool}

Analysis of GSLs was performed with the method of Gallaher et al. (2012) as described in our previous studies (Klimek-Szczykutowicz et al. 2019, 2020b). Briefly, lyophilized and pulverized samples were extracted after myrosinase inactivation. The centrifuged extract was evaporated under $\mathrm{N}_{2}$ (TurboVap evaporator, Zymark, Midland, MI, USA), and after reconstitution in $\mathrm{H}_{2} \mathrm{O}$, the samples were subjected to anion-exchange SPE (Supel-Select SAX, $60 \mathrm{mg}$, $3 \mathrm{~mL}$, Bellefonte, PA, USA) to clean up. The GSLs were eluted with $4 \times 0.25 \mathrm{~mL}$ of $0.5 \mathrm{M} \mathrm{NaCl}$ then dried under $\mathrm{N}_{2}$, and the GSLs were hydrolysed with $1 \mathrm{M}$ sodium hydroxide. After $30 \mathrm{~min}$, the samples were neutralized with concentrated hydrochloric acid. The colorimetric reaction of $2 \mathrm{mM}$ potassium ferricyanide solution $(0.4 \mathrm{M}$ phosphate buffer $\mathrm{pH}$ 7.0 ) with the standard or sample solution was monitored in 
96-well plates. Absorbance was read at $420 \mathrm{~nm}$ (Synergy II, BioTek, Winooski, VT, USA) 2 min after ferricyanide addition. The total GSL content was expressed as sinigrin equivalent in mg of sinigrin/100 g DW. All the technical details were given earlier by Klimek-Szczykutowicz et al. (2019, 2020b).

\section{Total flavonoid assay}

The pool of flavonoids was estimated spectrophotometrically according to Ramos et al. (2017). Forty microliters of $10 \%$ $\mathrm{AlCl}_{3}$ was mixed with $100 \mu \mathrm{L}$ of methanolic extract and samples were filled to $1000 \mu \mathrm{L}$ with $5 \%$ acetic acid. After 20 min incubation at room temperature, the samples were aliquoted to 96-well plates and the absorbance was recorded (425 nm, Synergy II, BioTek, Winooski, VT, USA). The sum of flavonoids was calculated as mg rutoside equivalent (RE)/100 g DW. The measurements were done in triplicate (including reagent blanks).

\section{Total polyphenolic assay}

Estimation of the total polyphenolic content was done according to the Singleton method (Singleton et al. 1999) with modifications (Bach et al. 2015). The methanolic extracts were prepared as described in "Sample preparation". Water-diluted Folin-Ciocalteu (F-C) phenol reagent $(5 / 2 \mathrm{v} / \mathrm{v}, 0.45 \mathrm{~mL})$ was mixed with the sample extracts $(100$ $\mu \mathrm{L})$. After $10 \mathrm{~min}$, saturated $\mathrm{Na}_{2} \mathrm{CO}_{3}(0.45 \mathrm{~mL})$ was added. The incubation of the samples was continued for $2 \mathrm{~h}$ in darkness at $25^{\circ} \mathrm{C}$. Then, the samples were centrifuged and aliquoted to 96-well plates. The absorbance was detected at $760 \mathrm{~nm}$ (Synergy II, BioTek, Winooski, VT, USA). The pool of phenolic compounds was calculated as $\mathrm{mg}$ gallic acid equivalent (GAL)/100 g DW. The analysis was done in triplicate (including reagent blanks).

\section{Total soluble saccharide determination}

To analyze soluble saccharides, the Dubois et al. (1951) phenol-sulfuric method modified by Bach et al. (2015) was used. Samples $(5 \mathrm{mg})$ were extracted in $1.5 \mathrm{~mL}$ of ultrapure water for $15 \mathrm{~min}$, and then centrifuged at $22000 \times \mathrm{g}$ for $5 \mathrm{~min}$ at $15{ }^{\circ} \mathrm{C}$. A $20 \mu \mathrm{L}$ sample of the supernatant was diluted with $180 \mu \mathrm{L}$ water. Then, $200 \mu \mathrm{L}$ of a $5 \%$ phenol solution and $1 \mathrm{~mL}$ concentrated sulfuric acid were added. Samples were left for $20 \mathrm{~min}$ incubation and transferred to 96-well plates. The absorbance was measured at $490 \mathrm{~nm}$. The saccharide content was expressed as glucose (GLU) equivalent.

\section{Analysis of individual glucosinolate content}

Isolation of desulfoglucosinolates (dGSLs) was performed as reported previously (Grosser and van Dam 2017; Blažević et al. 2019) from $100 \mathrm{mg}$ samples of dried plant material. The standard used, sinigrin, was obtained from SigmaAldrich (Saint Louis, MO, USA); glucohesperin (1), glucohirsutin (3), gluconasturtiin (6), 4-hydroxyglucobrassicin (7), glucobrassicin $(\mathbf{8})$, and 4-methoxyglucobrassicin (9) were obtained from Phytoplan (Heidelberg, Germany). All other chemicals and reagents were of analytical grade.

Analysis was performed by the UHPLC-DAD-MS/MS method (Ultimate 3000RS with TSQ Quantis MS/MS detector, Thermo Fischer Scientific, Waltham, MA, USA) using a Hypersil GOLD column $(3.0 \mu \mathrm{m}, 3.0 \times 100 \mathrm{~mm}$, Thermo Fischer Scientific, Waltham, MA, USA). A gradient consisting of solvent $\mathrm{A}\left(50 \mu \mathrm{M} \mathrm{NaCl}\right.$ in $\left.\mathrm{H}_{2} \mathrm{O}\right)$ and solvent $\mathrm{B}$ (acetonitrile: $\mathrm{H}_{2} \mathrm{O} 30: 70 \mathrm{v} / \mathrm{v}$ ) was applied at a flow rate of $0.5 \mathrm{~mL} / \mathrm{min}$ as follows: $0.14 \mathrm{~min} 96 \% \mathrm{~A}$ and $4 \% \mathrm{~B} ; 7.84 \mathrm{~min}$ $14 \% \mathrm{~A}$ and $86 \% \mathrm{~B} ; 8.96 \mathrm{~min} 14 \% \mathrm{~A}$ and $86 \% \mathrm{~B} ; 9.52 \mathrm{~min} 5 \%$ $\mathrm{A}$ and $95 \% \mathrm{~B} ; 13.16 \min 5 \% \mathrm{~A}$ and $95 \% \mathrm{~B} ; 13.44 \min 96 \%$ $\mathrm{A}$ and $4 \% \mathrm{~B} ; 15.68 \mathrm{~min} 96 \% \mathrm{~A}$ and $4 \% \mathrm{~B}$. The column temperature was held at $15^{\circ} \mathrm{C}$, and the injection volume was 2 $\mu \mathrm{L}$. The system was operated in the positive ion electrospray mode and the electrospray interface was H-ESI operating with a capillary voltage of $3.5 \mathrm{kV}$ at $350{ }^{\circ} \mathrm{C}$. The signals were recorded at $227 \mathrm{~nm}$ by a diode array detector (DAD). Quantification of dGSLs was performed using an external calibration curve of pure desulfosinigrin (range from 13.56- 542.50 $\mu \mathrm{M}$ ). For each individual dGSL response, factors (RPF) were taken in accordance with the literature: RPF 1.0 for $\mathbf{1}$ and 4, 1.1 for $\mathbf{3}$ and 5 (Brown et al. 2003), 0.95 for 6, 0.28 for 7, 0.29 for $\mathbf{8}, 0.25$ for $\mathbf{9}$ (Wathelet et al. 2004); arbitrary 1.0 for $\mathbf{2}$ (Supplementary Fig. S1).

\section{Analysis of polyphenol compounds by HPLC-DAD}

The analysis was performed using the HPLC-DAD method described previously (Ellnain-Wojtaszek and Zgórka 1999; Sułkowska-Ziaja et al. 2017). For the estimation, methanolic extracts were used (prepared as described in "Sample preparation"). An HPLC-DAD system (Merck-Hitachi, Merck KGaA, Darmstadt, Germany) and a Purospher RP$18 \mathrm{e}$ analytical column $(4 \times 250 \mathrm{~nm}, 5 \mathrm{~mL}$; Merck $)$ were used. Elution was done with a mobile phase A (methanol:0.5\% acetic acid, $1: 4 \mathrm{v} / \mathrm{v}$ ) and a mobile phase B (methanol). The gradient program was set as follows: $0-20 \mathrm{~min}$, 0\% B; 20-35 min, 0-20\% B; 35-45 min, 20-30\% B; 45-55 min, 30-40\% B; 55-60 min, 40-50\% B; 60-65 min, $50-75 \% \mathrm{~B}$; and $65-70 \mathrm{~min}, 75-100 \% \mathrm{~B}$. The hold time was $15 \mathrm{~min}$. The other parameters were as follows: temperature $25^{\circ} \mathrm{C}$, flow rate $1 \mathrm{~mL} / \mathrm{min}$, injection volume $20 \mu \mathrm{L}$, and detection wavelength $254 \mathrm{~nm}$. Quantitative analysis was 
carried out for the following compounds identified previously using the UHPLC-DAD-ESI-MS method (KlimekSzczykutowicz et al. 2020a): $p$-coumaric acid, ferulic acid, and rutoside (Sigma-Aldrich Co. St. Louis, MO, USA).

\section{Analysis of photosynthetic pigments}

Chlorophylls and carotenoids were estimated spectrophotometrically according to Czyczyło-Mysza et al. (2013). Plant material was extracted with $96 \%$ ethanol; centrifuged extract $\left(21,000 \times \mathrm{g}, 5 \mathrm{~min}\right.$ at $\left.15^{\circ} \mathrm{C}\right)$ was transferred to a 96-well micro-plate, and the absorbance was read at 470, 648, and $664 \mathrm{~nm}$ (Synergy II, BioTek, Winooski, VT, USA). The concentration of chlorophyll $a$, chlorophyll $b$, total chlorophyll $(a+b)$, and total carotenoids (c) was calculated with Lichtenthaler and Buschman (2001) equations, taking into account the path length of the micro-well.

\section{Antioxidant activity assays}

\section{CUPRAC (CUPric Reducing Antioxidant Capacity) assay}

The CUPRAC method (Özyürek et al. 2007) with subsequent modifications (Biesaga-Kościelniak et al. 2014) was used to measure the total antioxidant capacity in the analyzed biomass extracts. Equal volumes of methanolic extracts (prepared as described in "Sample preparation"), $10 \mathrm{mmol} / \mathrm{L} \mathrm{Cu}^{2+}, 7.5 \mathrm{mmol} / \mathrm{L}$ neocuproine, and $1 \mathrm{~mol} / \mathrm{L}$ ammonia-acetate buffer ( $\mathrm{pH} 7.0)$ were sequentially dispensed. The samples were mixed and after $15 \min \left(25^{\circ} \mathrm{C}\right)$, incubation the absorbance was recorded at $425 \mathrm{~nm}$ (96well plates, Synergy II, BioTek, Winooski, VT, USA). The antioxidant accumulation was calculated as mmol Trolox equivalent (TE)/100 g DW. The measurements were done in triplicate (including reagent blanks).

\section{FRAP (Ferric Reducing Antioxidant Power) assay}

The antioxidant capacity of the biomass methanolic extracts was also estimated employing the FRAP method (Benzie and Strain 1996). The reagent consisted of a $10 \mathrm{mmol} / \mathrm{L}$ TPTZ (2,4,6-tris(2-pyridyl)-s-triazine) soluted in $40 \mathrm{mmol} / \mathrm{L} \mathrm{HCl}$ with addition of $\mathrm{FeCl}_{3} \cdot 6 \mathrm{H}_{2} \mathrm{O}(20 \mathrm{mmol} / \mathrm{L})$ and $300 \mathrm{mmol} / \mathrm{L}$ of a pH 3.6 acetate buffer $(1: 1: 10 \mathrm{v} / \mathrm{v} / \mathrm{v})$. Fifty microliters of extracts was poured with $150 \mu \mathrm{L}$ of the prepared reagent. After 5 min incubation, the absorbance of the sample was read at $593 \mathrm{~nm}$ (96-well plates, Synergy II, BioTek, Winooski, VT, USA). The measurements were done in triplicate (including reagent blanks).
DPPH (2,2-diphenyl-1-picrylhydrazyl) radical-scavenging activity assay

The free radical-scavenging activity of the extracts was estimated with the use of the stable radical DPPH (Blios 1958). Fifty microliters of extracts was mixed with $150 \mu \mathrm{L}$ of DPPH methanolic solution. The samples were incubated for $60 \mathrm{~min}$, and then, its absorbance was read at $517 \mathrm{~nm}$ (96-well plates, Synergy II, BioTek, Winooski, VT, USA). The measurements were performed in triplicate (including reagent blanks).

\section{Inhibition of tyrosinase}

The influence of extracts from $N$. officinale microshoot cultures treated with $100 \mu \mathrm{M}$ MeJA and collected after $24 \mathrm{~h}$ on the inhibition of tyrosinase was assessed using the method developed by Chien et al. (2008) and described in previous work (Sułkowska-Ziaja et al. 2021). For this test, we chose the most abundant microshoots based on phytochemical estimations.

The degree of inhibition was determined by spectrophotometry from the UV spectrum with modifications. The percentage of inhibition was estimated by measuring the absorbance of the tested mixtures at $274 \mathrm{~nm}$. At the same time, the spectra of the entire UV range were monitored to identify any undesirable absorption spectrum that could indicate additional reactions in the analyzed mixtures. The evaluation was carried out in a phosphate buffer solution with $\mathrm{pH} 6.84$, in which the analyzed extracts were dissolved. The prepared tyrosinase control solution contained 350 units of enzyme in $1.0 \mathrm{~mL}$. The inhibiting activity was expressed as a percentage of enzyme inhibition, and the assessment of the force of action was carried out relative to kojic acid. The analyzed mixtures were incubated at $37^{\circ} \mathrm{C}$ for $25 \mathrm{~min}$. Subsequently, an absorption spectrum was obtained within the wave-length range of $200-400 \mathrm{~nm}$ in which a well-developed maximum was observed at $274 \mathrm{~nm}$. The absorption at the maximum was used to evaluate the inhibiting action of the analyzed extracts or kojic acid (control) on tyrosinase activity (Sigma-Aldrich, St. Louis, MO, USA). The impact of the extracts on the enzyme activity was determined using the formula: $(\%$ inhibition $)=\left[1-\left(A-\mathrm{A}_{0}\right) /\left(B-\mathrm{B}_{0}\right)\right] \times 100$, where $A$ is the absorbance of the test sample (with tyrosinase, $1=274 \mathrm{~nm}$ )., $A_{0}$ is the absorbance of the test sample (without tyrosinase, $1=274 \mathrm{~nm}$ ), $B_{0}$ is the absorbance of the control sample (with tyrosinase, $1=274 \mathrm{~nm}$ ) and $\mathrm{B}_{0}$ is the absorbance of the blank sample (without tyrosinase, $1=274 \mathrm{~nm}$ ).

\section{Results}

\section{Microshoot appearance and biomass growth}

The appearance of $N$. officinale microshoots is affected by the applied elicitors and their concentrations, and also 


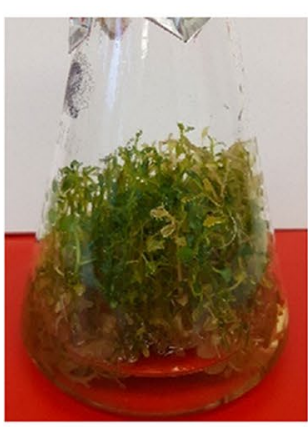

A

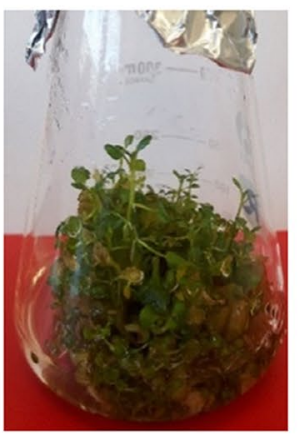

F

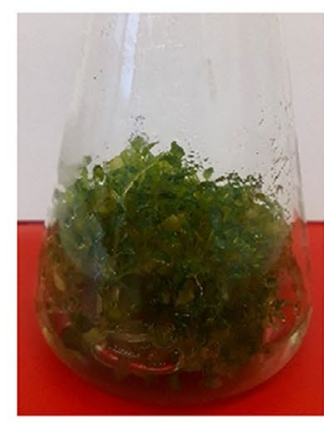

B

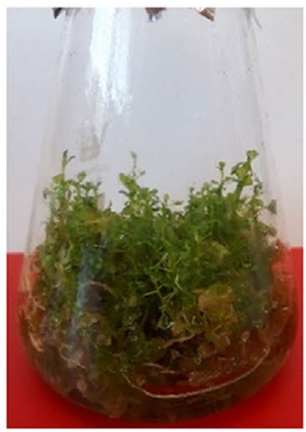

G

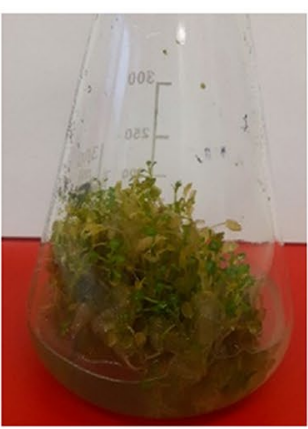

C

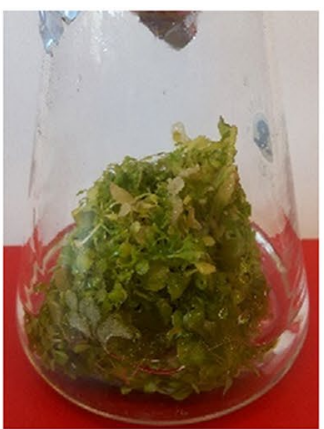

D

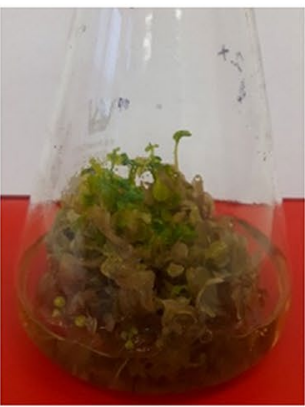

H

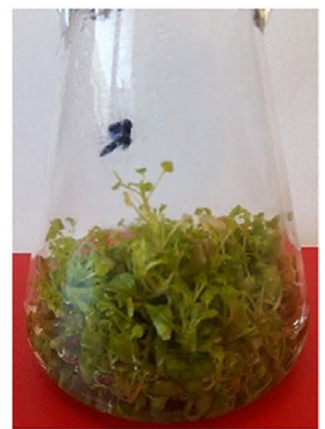

$\mathbf{E}$

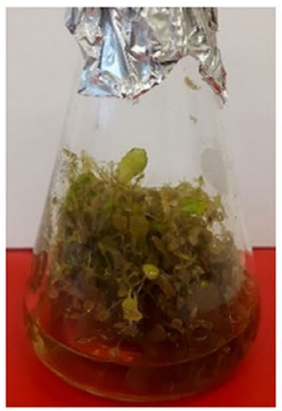

I
Fig. 1 Examples of the morphological appearance of $N$. officinale control and experimental in vitro cultures after 8 days of elicitation. Used concentrations of elicitors: A control, B $25 \mu \mathrm{M}$ ETH, C $50 \mu \mathrm{M}$

the day of growth after elicitor addition (Supplementary Fig. S2). Microshoots grown with $25 \mu \mathrm{M}$ ETH were characterized by a green color throughout the entire growth period. The concentration of $50 \mu \mathrm{M}$ of ETH caused the biomass to die 6 and 8 days after elicitor addition (Fig. 1). In both MeJA concentrations used, the microshoots were smaller and lighter in color 6 and 8 days after elicitor addition (Fig. 1). The microshoots grown with NaSA were vigorous and of a dark green color for the entire period of growth. An increase in the concentration of this elicitor caused no change in the appearance of the cultures. The $N$. officinale cultures grown on MS medium with YeE were characterized by the smallest increase in microshoot biomass at the elicitor concentration of $3 \mathrm{mg} / \mathrm{mL}$. With
ETH, D $50 \mu \mathrm{M}$ MeJA, E $100 \mu \mathrm{M}$ MeJA, F $50 \mu \mathrm{M}$ NaSA, G $100 \mu \mathrm{M}$ NaSA, H $1 \mathrm{mg} / \mathrm{mL}$ YeE, I $3 \mathrm{mg} / \mathrm{mL}$ YeE. Figure 1 is corresponding with Supplementary Fig. S2

both YeE concentrations $(1 \mathrm{mg} / \mathrm{mL}$ and $3 \mathrm{mg} / \mathrm{mL}), 6$ and 8 days after adding the elicitor, the cultures were close to dying (Fig. 1). In control cultures (C), the microshoots were large and green until 4 days after adding the elicitor. After 6 and 8 days, the microshoots became lighter in color (Fig. 1).

The growth index $(\mathrm{Gi})$ for the tested elicitation variants ranged from 6.47 to 31.59 . The lowest $\mathrm{Gi}$ was obtained with $25 \mu \mathrm{M}$ ETH for microshoots collected after $24 \mathrm{~h}$ of treatment (Table 1 and Supplementary Table S1). The highest Gi was obtained after 6 days of elicitation with $100 \mu \mathrm{M}$ MeJA. A high Gi was also reached with $50 \mu \mathrm{M}$ NaSA after $48 \mathrm{~h}$ of treatment $(\mathrm{Gi}=31.04)$. The $\mathrm{Gi}$ in $\mathrm{C}$ ranged from 20.93 to
Table 1 Maximum values of the growth index $(\mathrm{Gi} \pm \mathrm{SD})$ for $N$. officinale control and experimental in vitro cultures after elicitation $(p<0.05$ vs control, $n=6$ )

\begin{tabular}{lllll}
\hline Elicitor & Gi \pm SD maximal value & $\begin{array}{l}\text { Elicitor concen- } \\
\text { tration }\end{array}$ & $\begin{array}{l}\text { Harvest time after elici- } \\
\text { tor treatments }\end{array}$ & Gi \pm SD of C \\
\hline ETH & $30.26 \pm 0.03$ & $25 \mu \mathrm{M}$ & 4 days & $29.91 \pm 0.15$ \\
MeJA & $31.59 \pm 0.01$ & $100 \mu \mathrm{M}$ & 6 days & $30.17 \pm 0.32$ \\
NaSA & $31.04 \pm 0.07$ & $50 \mu \mathrm{M}$ & $48 \mathrm{~h}$ & $30.32 \pm 0.07$ \\
YeE & $29.27 \pm 0.07$ & $3 \mathrm{mg} / \mathrm{mL}$ & $48 \mathrm{~h}$ & $30.32 \pm 0.07$ \\
\hline
\end{tabular}

*Table 1 is corresponding to Supplementary Table S1 
30.32. The highest $\mathrm{Gi}$ for $\mathrm{C}$ was obtained after $48 \mathrm{~h}$, and the lowest after $24 \mathrm{~h}$ (Table 1 and Supplementary Table S1).

\section{Total and individual GSL content}

In order to monitor the total GSL content during plant development, the rapid and cost-effective spectrophotometric method was initially used. The results are given in Supplementary Table S2. The total amount of GSLs was dependent on the addition of the elicitors, their concentrations, and harvesting time. The results of analysis of total GSL content gave us the rationale for choosing the most productive strategies of each elicitor tested: $25 \mu \mathrm{M}$ ETH (4 days), $50 \mu \mathrm{M}$ MeJA ( $24 \mathrm{~h}$ ), $50 \mu \mathrm{M}$ NaSA (4 days), and $3 \mathrm{mg} / \mathrm{mL}$ YeE (6 days). These samples were subjected to a thorough UHPLC-DAD-MS/MS qualitative and quantitative analyses (Tables 2-3 and Supplementary Fig. S1). In total, nine GSLs were found in the analyzed extracts, namely glucohesperin (1), 7-(methylsulfinyl)heptyl GSL (2), glucohirsutin (3), 7-(methylsulfanyl)heptyl GSL (4), 8-(methylsulfanyl)octyl GSL (5), gluconasturtiin (6), 4-hydroxyglucobrassicin (7), glucobrassicin (8), and 4-methoxyglucobrassicin (9). The amounts of individual compounds in the analyzed extracts ranged from 0.55 to $152.91 \mathrm{mg} / 100 \mathrm{~g}$ DW. The main GSLs according to their amounts were $\mathbf{9 , 8}$, and $\mathbf{6}$.

\section{Total and individual flavonoid and polyphenol contents}

The study has confirmed the influence of the kind of elicitor, its concentration, and the duration of growth on the total amount of flavonoids in extracts of $N$. officinale microshoots. The total amount of flavonoids ranged from 305.86 to $1131.33 \mathrm{mg}$ rutoside equivalent (RE)/100 g DW. The lowest flavonoid content was estimated for C collected after $48 \mathrm{~h}$. The highest flavonoid content was obtained after $24 \mathrm{~h}$ of elicitation with $100 \mu \mathrm{M}$ NaSA (1131.33 mg RE/100 g) and after 8 days of elicitation with $50 \mu \mathrm{M}$ NaSA $(1129.14 \mathrm{mg}$ $\mathrm{RE} / 100 \mathrm{~g} \mathrm{DW}$ ). A high flavonoid content was also estimated for cultures elicited with ETH at $25 \mu \mathrm{M}(1012.47 \mathrm{mg}$ $\mathrm{RE} / 100 \mathrm{~g} \mathrm{DW})$ and $50 \mu \mathrm{M}(1060.80 \mathrm{mg} \mathrm{RE} / 100 \mathrm{~g} \mathrm{DW})$, and collected after 4 days and $48 \mathrm{~h}$, respectively. The YeE showed the least impact on the production of flavonoids in the analyzed $N$. officinale microshoots. The maximum content for $1 \mathrm{mg} / \mathrm{mL}$ YeE (824.18 mg RE/100 g DW) and $3 \mathrm{mg} / \mathrm{mL} \mathrm{YeE} \mathrm{(633.58} \mathrm{mg} \mathrm{RE/100} \mathrm{g} \mathrm{DW)} \mathrm{was} \mathrm{obtained} \mathrm{after}$ 8 days and $24 \mathrm{~h}$, respectively. The highest amount of flavonoids after elicitation with MeJA at $50 \mu \mathrm{M}(904.36 \mathrm{mg} / 100 \mathrm{~g}$ DW) and $100 \mu \mathrm{M}(1037.47 \mathrm{mg} \mathrm{RE} / 100 \mathrm{~g} \mathrm{DW})$ was obtained after 4 days and $24 \mathrm{~h}$, respectively (Table 2 and Supplementary Table S2).

The total amounts of polyphenols in N. officinale microshoots ranged from 131.89 to $336.89 \mathrm{mg} \mathrm{GAL} / 100 \mathrm{~g}$ DW.

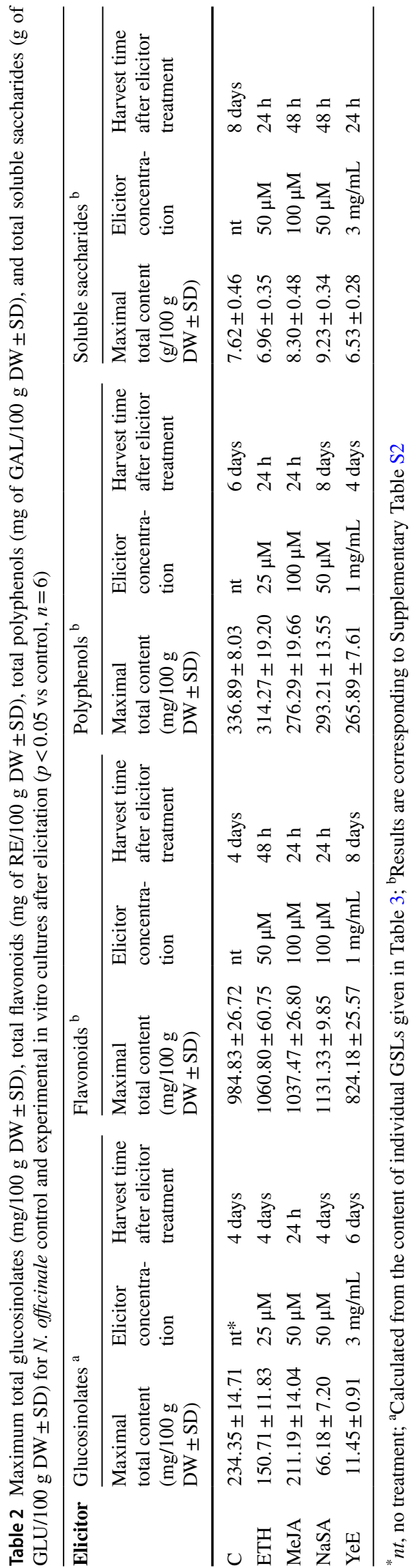


Table 3 Qualitative and quantitative $(\mathrm{mg} / 100 \mathrm{~g}$ DW $\pm \mathrm{SD})$ profiles of GSL compounds detected in N. officinale control and selected experimental in vitro cultures after elicitation, as confirmed by UHPLC-DAD-MS/MS

\begin{tabular}{|c|c|c|c|c|c|c|c|c|c|}
\hline \multirow[t]{2}{*}{ Subgroups } & \multirow[t]{2}{*}{ No.* } & \multirow{2}{*}{$\begin{array}{l}\text { Glucosinolate } \\
\text { (GSL) (trivial } \\
\text { name) }\end{array}$} & \multirow[t]{2}{*}{$t_{\mathrm{R}}(\min )$} & \multirow[t]{2}{*}[\mathrm{M}+\mathrm{Na}]{$^{+}$} & \multicolumn{5}{|c|}{ Contents $(\mathrm{mg} / 100 \mathrm{~g} \mathrm{DW} \pm \mathrm{SD})$} \\
\hline & & & & & C 4 days & $\begin{array}{l}25 \mu \mathrm{M} \text { ETH } \\
4 \text { days }\end{array}$ & $\begin{array}{l}50 \mu \mathrm{M} \text { MeJA } \\
24 \mathrm{~h}\end{array}$ & $\begin{array}{l}50 \mu \mathrm{M} \text { NaSA } \\
4 \text { days }\end{array}$ & $\begin{array}{l}3 \mathrm{mg} / \mathrm{mL} \mathrm{YeE} \\
6 \text { days }\end{array}$ \\
\hline \multirow[t]{5}{*}{$\begin{array}{c}\text { Methionine } \\
\text { derived }\end{array}$} & 1 & $\begin{array}{l}\text { 6-(Methylsulfi- } \\
\text { nyl)hexyl } \\
\text { GSL (gluco- } \\
\text { hesperin) }\end{array}$ & 5.50 & 408 & nd & $\operatorname{tr}$ & nd & nd & nd \\
\hline & 2 & $\begin{array}{l}\text { 7-(Methylsulfi- } \\
\text { nyl)heptyl } \\
\text { GSL }\end{array}$ & 6.55 & 422 & $\operatorname{tr}$ & $\operatorname{tr}$ & $\operatorname{tr}$ & $\operatorname{tr}$ & $\operatorname{tr}$ \\
\hline & 3 & $\begin{array}{l}\text { 8-(Methyl- } \\
\text { sulfinyl)octyl } \\
\text { GSL (gluco- } \\
\text { hirsutin) }\end{array}$ & 7.58 & 436 & $\operatorname{tr}$ & $\operatorname{tr}$ & $\operatorname{tr}$ & $\operatorname{tr}$ & nd \\
\hline & 4 & $\begin{array}{l}\text { 7-(Methylsul- } \\
\text { fanyl)heptyl } \\
\text { GSL }\end{array}$ & 10.97 & 406 & $\operatorname{tr}$ & nd & $\operatorname{tr}$ & $\operatorname{tr}$ & nd \\
\hline & 5 & $\begin{array}{l}\text { 8-(Methylsul- } \\
\text { fanyl)octyl } \\
\text { GSL }\end{array}$ & 12.70 & 420 & $\operatorname{tr}$ & nd & nd & $\operatorname{tr}$ & nd \\
\hline $\begin{array}{l}\text { Phenylalanine } \\
\text { derived }\end{array}$ & 6 & $\begin{array}{l}\text { 2-Phenylethyl } \\
\text { GSL (gluco- } \\
\text { nasturtiin) }\end{array}$ & 8.20 & 366 & $23.16 \pm 4.16$ & $42.79 \pm 4.83$ & $68.34 \pm 5.14$ & $7.17 \pm 0.19$ & $\operatorname{tr}$ \\
\hline \multirow[t]{3}{*}{$\begin{array}{l}\text { Tryptophan } \\
\text { derived }\end{array}$} & 7 & $\begin{array}{l}\text { 4-Hydroxyin- } \\
\text { dol-3-ylme- } \\
\text { thyl GSL } \\
\text { (4-hydroxy- } \\
\text { glucobras- } \\
\text { sicin) }\end{array}$ & 5.85 & 407 & $12.00 \pm 1.89$ & $1.36 \pm 0.10$ & $5.26 \pm 1.57$ & $0.55 \pm 0.00$ & nd \\
\hline & 8 & $\begin{array}{l}\text { Indol-3-ylme- } \\
\text { thyl GSL } \\
\text { (glucobras- } \\
\text { sicin) }\end{array}$ & 7.64 & 391 & $46.28 \pm 3.20$ & $34.36 \pm 0.67$ & $65.95 \pm 0.49$ & $4.15 \pm 0.12$ & $\operatorname{tr}$ \\
\hline & 9 & $\begin{array}{l}\text { 4-Methoxyin- } \\
\text { dol-3-ylme- } \\
\text { thyl GSL } \\
\text { (4-methoxy- } \\
\text { glucobras- } \\
\text { sicin) }\end{array}$ & 8.35 & 421 & $152.91 \pm 5.46$ & $72.20 \pm 6.23$ & $71.64 \pm 6.84$ & $54.31 \pm 6.89$ & $11.45 \pm 0.91$ \\
\hline
\end{tabular}

$[\mathrm{M}+\mathrm{Na}]^{+}$, sodium adduct of desulfoglucosinolate; $t r$, trace amounts $<0.1 \mathrm{mg} / 100 \mathrm{~g} \mathrm{DW} ; n d$, not detected

*Numbers are corresponding to Supplementary Fig. S1

The highest polyphenol content was estimated for $\mathrm{C}$ microshoots collected after 6 days. The maximal total polyphenol content for the elicited cultures obtained in microshoots treated with ETH was a little lower than for C (for $25 \mu \mathrm{M}$, $314.27 \mathrm{mg} \mathrm{GAL} / 100 \mathrm{~g}$ DW and for $50 \mu \mathrm{M}, 293.91 \mathrm{mg}$ GAL/100 g DW, for samples collected after $24 \mathrm{~h}$ and 6 days, respectively). For elicitation with 50 and $100 \mu \mathrm{M} \mathrm{NaSA}$, the maximum amounts of polyphenols (293.21 and $268.30 \mathrm{mg}$ GAL/100 g DW) were confirmed after 8 and 4 days of treatment. For elicitation with 1 and $3 \mathrm{mg} / \mathrm{mL} \mathrm{YeE}$, the maximum contents were lower than for all the other elicitors. The maximum values of 265.89 and $255.84 \mathrm{mg} \mathrm{GAL} / 100 \mathrm{~g}$
DW, respectively, were obtained after 4 days of treatments. The maximum amounts of polyphenols for $50 \mu \mathrm{M}$ MeJA (269.61 mg GAL/100 g DW) and $100 \mu \mathrm{M}$ MeJA (276.29 mg GAL/100 g DW) were estimated in microshoots collected after 4 and 8 days, respectively (Table 2 and Supplementary Table S2).

Under our former study (Klimek-Szczykutowicz et al. 2020a), using the UHPLC-DAD-MS/MS method, we confirmed the presence of individual phenolic compounds in $N$. officinale microshoot extracts. Within this study, we estimated quantitatively two phenolic acids ( $p$-coumaric and ferulic) and one flavonoid (rutoside) with the HPLC-DAD 
Table 4 Maximum amounts of the main phenolic compounds $(\mathrm{mg} / 100 \mathrm{~g} \mathrm{DW} \pm \mathrm{SD})$ in extracts from $N$. officinale control and experimental in vitro cultures after elicitation ( $p<0.05$ vs control, $n=6$ )

\begin{tabular}{llllll}
\hline Polyphenol compounds & $\begin{array}{l}\text { Maximal content } \\
(\mathrm{mg} / 100 \mathrm{~g} \mathrm{DW} \pm \mathrm{SD})\end{array}$ & Elicitor & $\begin{array}{l}\text { Elicitor concen- } \\
\text { tration }\end{array}$ & $\begin{array}{l}\text { Harvest time after elici- } \\
\text { tor treatment }(\mathrm{mg} / 100 \mathrm{~g} \text { DW } \pm \mathrm{SD})\end{array}$ \\
\hline p-Coumaric acid & $38.76 \pm 0.72$ & MeJA & $100 \mu \mathrm{M}$ & 6 days & $64.38 \pm 9.26$ \\
Ferulic acid & $17.76 \pm 2.07$ & $\mathrm{NaSA}$ & $50 \mu \mathrm{M}$ & 8 days & $16.46 \pm 0.09$ \\
Rutoside & $17.00 \pm 1.45$ & $\mathrm{NaSA}$ & $100 \mu \mathrm{M}$ & 8 days & $21.17 \pm 2.67$ \\
\hline
\end{tabular}

*Table 4 is corresponding to Supplementary Table S3

method (Table 4 and Supplementary Table S3). The amount of $p$-coumaric acid ranged from 1.80 to $64.38 \mathrm{mg} / 100 \mathrm{~g}$ DW. The lowest content was obtained for microshoots collected after $24 \mathrm{~h}$ of treatment with $50 \mu \mathrm{M}$ ETH. The highest content was estimated for samples from $\mathrm{C}$ harvested after 8 days. In elicitor-treated samples, the maximum value for $p$-coumaric acid (38.76 mg/100 g DW) was obtained after elicitation with $100 \mu \mathrm{M}$ MeJA (after 6 days) (Table 4 and Supplementary Table S3). The amount of ferulic acid varied from 1.39 to $17.76 \mathrm{mg} / 100 \mathrm{~g}$ DW. The lowest content was obtained in the $\mathrm{C}$ after $48 \mathrm{~h}$. The highest content was found in microshoots collected after 8 days of elicitation with $50 \mu \mathrm{M} \mathrm{NaSA}$. In $\mathrm{C}$, the maximum value for ferulic acid $(16.46 \mathrm{mg} / 100 \mathrm{~g} \mathrm{DW})$ was obtained after 8 days (Table 4 and Supplementary Table S3). The amount of rutoside in extracts from the analyzed $N$. officinale microshoot cultures ranged from 1.14 to $21.17 \mathrm{mg} / 100 \mathrm{~g}$ DW. The lowest content was obtained in microshoot extracts collected after $48 \mathrm{~h}$ from cultures treated with $25 \mu \mathrm{M}$ ETH. The maximum value was obtained for $\mathrm{C}$ after 6 days. In extracts from the treated $N$. officinale microshoots, the highest content was obtained after 8 days of treatment with $100 \mu \mathrm{M}$ NaSA (Table 4 and Supplementary Table S3).

\section{Total soluble saccharide content}

The total amounts of soluble saccharides ranged from 1.97 to $9.23 \mathrm{~g} \mathrm{GLU} / 100 \mathrm{~g}$ DW (Table 2 and Supplementary Table S2). For C, the highest amount of soluble saccharides
(7.62 g GLU/100 g DW) was obtained after 8 days. The lowest amount of soluble saccharides was obtained after 6 days of treatment with $1 \mathrm{mg} / \mathrm{mL}$ YeE. In comparison with $\mathrm{C}$, the total soluble saccharide content increased after elicitation with $50 \mu \mathrm{M} \mathrm{NaSA}$ and $100 \mu \mathrm{M}$ MeJA after $48 \mathrm{~h}$ of treatment (Table 2 and Supplementary Table S2). The highest content was obtained with $50 \mu \mathrm{M} \mathrm{NaSA}$ after $48 \mathrm{~h}$ of elicitation (9.23 g GLU/100 g DW) and for $100 \mu \mathrm{M}$ MeJA after $48 \mathrm{~h}$ (8.30 g GLU/100 g DW).

\section{Photosynthetic pigment contents}

The analysis has proven the influence of elicitors on the production of photosynthetic pigments in extracts from $N$. officinale microshoot cultures. The amount of chlorophyll $a$ ranged from 4.38 to $89.01 \mathrm{mg} / 100 \mathrm{~g} \mathrm{DW}$. The lowest value was obtained after $48 \mathrm{~h}$ for $\mathrm{C}$. The maximum content was in the microshoots collected after $24 \mathrm{~h}$ from the cultures supplemented with $100 \mu \mathrm{M}$ NaSA. The high value $(85.56 \mathrm{mg} / 100 \mathrm{~g} \mathrm{DW})$ for chlorophyll $a$ was obtained also in $\mathrm{C}$ after 4 days (Table 5 and Supplementary Table S4).

The amount of chlorophyll $b$ in extracts from the experimental $N$. officinale cultures varied from 1.56 to $58.25 \mathrm{mg} / 100 \mathrm{~g}$ DW. The lowest content was obtained after $48 \mathrm{~h}$ for $\mathrm{C}$. The maximum value was estimated for microshoots collected $24 \mathrm{~h}$ after treatment with $100 \mu \mathrm{M}$ NaSA (Table 5 and Supplementary Table S4).

The total value of chlorophylls $a$ and $b$ in the analyzed extracts ranged from 5.99 to $147.32 \mathrm{mg} / 100 \mathrm{~g} \mathrm{DW}$. The

Table 5 Maximum amounts of photosynthetic pigments $(\mathrm{mg} / 100 \mathrm{~g} \mathrm{DW} \pm \mathrm{SD})$ in extracts from $N$. officinale control and experimental in vitro cultures after elicitation $(p<0.05$ vs control, $n=6)$

\begin{tabular}{|c|c|c|c|c|c|}
\hline Photosynthetic pigments & $\begin{array}{l}\text { Maximal content } \\
(\mathrm{mg} / 100 \mathrm{~g} \mathrm{DW} \pm \mathrm{SD})\end{array}$ & Elicitor & $\begin{array}{l}\text { Elicitor concen- } \\
\text { tration }\end{array}$ & $\begin{array}{l}\text { Harvest time after elici- } \\
\text { tor treatment }\end{array}$ & $\mathrm{C}(\mathrm{mg} / 100 \mathrm{~g} \mathrm{DW} \pm \mathrm{SD})$ \\
\hline Chlorophyll $a$ & $89.01 \pm 2.53$ & NaSA & $100 \mu \mathrm{M}$ & $24 \mathrm{~h}$ & $12.33 \pm 0.33$ \\
\hline Chlorophyll $b$ & $58.25 \pm 1.87$ & $\mathrm{NaSA}$ & $100 \mu \mathrm{M}$ & $24 \mathrm{~h}$ & $13.31 \pm 0.41$ \\
\hline Chlorophyll $a+b$ & $147.32 \pm 4.48$ & $\mathrm{NaSA}$ & $100 \mu \mathrm{M}$ & $24 \mathrm{~h}$ & $25.64 \pm 0.73$ \\
\hline Carotenoids & $10.83 \pm 1.14$ & $\mathrm{NaSA}$ & $50 \mu \mathrm{M}$ & 8 days & $1.67 \pm 0.06$ \\
\hline
\end{tabular}

*Table 5 is corresponding to Supplementary Table S4 
lowest content was in $\mathrm{C}$ after $48 \mathrm{~h}$. The maximum value was obtained for $100 \mu \mathrm{M}$ NaSA-elicited microshoots collected after $24 \mathrm{~h}$. A high total value of chlorophylls a and $b$ (141.50 mg/100 g DW) was estimated also in C after 4 days (Table 5 and Supplementary Table S4).

The amount of carotenoids in extracts of the experimental $N$. officinale cultures varied from 0.00 to $10.83 \mathrm{mg} / 100 \mathrm{~g}$ DW. The lack of carotenoids was shown for microshoots from $\mathrm{C}$ collected after 6 days. The highest content was obtained in the biomass harvested after 8 days of treatment with $50 \mu \mathrm{M} \mathrm{NaSA}$. In $\mathrm{C}$, the maximum amounts of carotenoids ( $9.33 \mathrm{mg} / 100 \mathrm{~g} \mathrm{DW})$ were obtained after 4 days (Table 5 and Supplementary Table S4).

\section{Antioxidant potential}

The three assays, CUPRAC, DPPH, and FRAP, were used to estimate the antioxidant potential of $N$. officinale microshoot extracts after elicitation. The antioxidant activity of biomass extracts analyzed with the CUPRAC method ranged from 0.84 to $2.97 \mathrm{mmol} \mathrm{TE} / 100 \mathrm{~g} \mathrm{DW}$. The lowest antioxidant activity was shown by $\mathrm{C}$ samples collected after $48 \mathrm{~h}$. The maximum antioxidant activity estimated with the CUPRAC method was obtained for microshoots collected after $24 \mathrm{~h}$ of elicitation with $100 \mu \mathrm{M}$ MeJA (Table 6). In the case of $\mathrm{C}$, the highest antioxidant potential (2.61 mmol TE/100 g DW) was obtained after 4 days (Supplementary Table S5).

The antioxidant activity of experimental biomass extracts estimated with the DPPH method ranged from 0.53 to $2.30 \mathrm{mmol} \mathrm{TE} / 100 \mathrm{~g}$ DW. The lowest antioxidant activity was obtained for microshoots treated with $50 \mu \mathrm{M}$ ETH and collected after $24 \mathrm{~h}$. The maximum antioxidant activity estimated with the DPPH method was obtained after elicitation of microshoots with $50 \mu \mathrm{M}$ ETH for 6 days (Table 6). In the case of $\mathrm{C}$ samples, the highest antioxidant potential (1.19 mmol TE/100 g DW) was shown by microshoots collected after $24 \mathrm{~h}$ (Supplementary Table S5).

The antioxidant activity of biomass extracts estimated with the FRAP method ranged from 0.15 to $0.83 \mathrm{mmol}$ TE/100 g DW. The lowest antioxidant activity was shown by extracts from the cultures treated with $3 \mathrm{mg} / \mathrm{mL}$ YeE and collected after 8 days. The maximum antioxidant activity was obtained after elicitation with $100 \mu \mathrm{M}$ MeJA for $24 \mathrm{~h}$ (Table 6). In $\mathrm{C}$ samples, the highest antioxidant potential (0.75 mmol TE/100 g DW) was shown after 4 days (Supplementary Table S5).

\section{Tyrosinase inhibition potential}

Under this study, we decided to check the possibility of using the analyzed extracts in the treatment of hypermelanosis. The tests of tyrosinase inhibition were performed on extracts of $N$. officinale microshoot cultures with a high antioxidant potential and high flavonoid and polyphenol contents (cultures treated with $100 \mu \mathrm{M}$ MeJA and collected after $24 \mathrm{~h}$ of elicitation). The results showed increased antityrosinase activity with increasing concentration of the tested extract. The inhibition ranged from 5.41 to $27.84 \%$. The highest inhibition was obtained for a concentration of dry extract equal to $1250 \mu \mathrm{g} / \mathrm{mL}$, and it was similar to tyrosinase inhibition with $5.5 \mu \mathrm{g} / \mathrm{mL}$ of kojic acid. The lowest inhibition was shown by extracts with a concentration of $250 \mu \mathrm{g}$ dry extract/mL (Table 7).

Table 7 Inhibition of tyrosinase activity $(\% \pm \mathrm{SD})$ by the extracts obtained from elicitor-treated $N$. officinale microshoot cultures $(p<0.05$ vs control, $n=6)$

\begin{tabular}{lllll}
\hline $\begin{array}{l}N . \text { officinale microshoot culture } \\
\text { extract }\end{array}$ & & Positive control \\
\cline { 1 - 2 } \cline { 5 - 5 } $\begin{array}{l}\text { N. officinale } \\
\text { extract }(\mu \mathrm{g} \text { dry } \\
\text { extract/mL) }\end{array}$ & $\begin{array}{l}\text { Inhibition of } \\
\text { tyrosinase } \\
\text { activity }\end{array}$ & & Kojic acid $(\mu \mathrm{g})$ & $\begin{array}{l}\text { Inhibition of } \\
\text { tyrosinase } \\
\text { activity }\end{array}$ \\
\hline 1250 & $27.84 \pm 0.40$ & & 5.5 & $30.62 \pm 0.36$ \\
1000 & $22.03 \pm 0.30$ & & 4.5 & $24.93 \pm 0.07$ \\
750 & $16.69 \pm 0.22$ & & 3.5 & $20.69 \pm 0.15$ \\
500 & $11.05 \pm 0.16$ & & 2.5 & $13.65 \pm 0.06$ \\
250 & $5.41 \pm 0.06$ & & 1.5 & $8.54 \pm 0.04$ \\
\hline
\end{tabular}

Table 6 Maximum antioxidant activity, estimated by the CUPRAC, DPPH, and FRAP methods (expressed in mmol TE/100 g DW \pm SD), of extracts from $N$. officinale control and experimental in vitro cultures after elicitation $(p<0.05$ vs control, $n=6)$

\begin{tabular}{llllll}
\hline Polyphenol compounds & $\begin{array}{l}\text { Maximal antioxidant } \\
\text { activity }\end{array}$ & Elicitor & Elicitor concentration & $\begin{array}{l}\text { Harvest time after elicitor } \\
\text { treatment }\end{array}$ \\
\hline CUPRAC & $2.97 \pm 0.03$ & MeJA & $100 \mu \mathrm{M}$ & $24 \mathrm{~h}$ & $1.63 \pm 0.06$ \\
DPPH & $2.30 \pm 2.09$ & ETH & $50 \mu \mathrm{M}$ & 6 days & $1.04 \pm 0.01$ \\
FRAP & $0.83 \pm 0.02$ & MeJA & $100 \mu \mathrm{M}$ & $24 \mathrm{~h}$ & $0.40 \pm 0.01$ \\
\hline
\end{tabular}

*Table 6 is corresponding to Supplementary Table S5 


\section{Discussion}

The influence of the applied elicitations on the biomass growth and appearance was assessed. In general, the elicitors used did not inhibit biomass growth. In our earlier studies, the highest Gi had been obtained for elicitor nontreated $N$. officinale agitated cultures $(\mathrm{Gi}=10.48)$ collected after 20 days of growth. That value was 3.0 times lower than the highest result obtained after the current treatments with elicitors (max. $\mathrm{Gi}=31.04$ ) (Klimek-Szczykutowicz et al. 2020b). The highest values of Gi obtained under our study were comparable to those reached by $N$. officinale microshoots maintained in special temporary immersion systems-RITA ${ }^{\circledR}$ bioreactors-over 20-day growth periods $(\mathrm{Gi}=31.71)$ (Klimek-Szczykutowicz et al. 2020a) (Table 1 and Supplementary Table S1).

The results of analysis of total GSL content gave us the rationale for choosing the most productive strategies of each elicitor tested (Supplementary Table S2). Based on UHPLCDAD-MS/MS qualitative and quantitative analyses in the $\mathrm{C}$ sample, the dominant compound was $\mathbf{9}$, while elicitation with $25 \mu \mathrm{M} \mathrm{ETH}$ and $50 \mu \mathrm{M}$ MeJA caused respectively 1.8 and 3.0 times higher accumulation of $\mathbf{6}$ in comparison with C. MeJA-treated microshoots contained 1.4 times higher and 2.1 times lower amounts of glucobrassicin and 4-methoxyglucobrassicin, respectively, in comparison with C (Table 3, Supplementary Fig. S1). UHPLC-DAD-MS/MS qualitative and quantitative analyses of $N$. officinale microshoot cultures grown in RITA® bioreactor had been performed by us also formerly (Klimek-Szczykutowicz et al. 2020a). There are noticeable differences between those results and the results for the elicitor-treated $N$. officinale microshoot cultures. The elicitors influenced both the qualitative and quantitative compositions of GSLs. In the bioreactor cultures, the dominant compound was Phe-derived 6 (182.93 mg/100 g DW), which was 2.7-fold higher than in the MeJA elicitortreated culture, where the maximum content was detected $(68.34 \mathrm{mg} / 100 \mathrm{~g} \mathrm{DW})$. Contrary to the bioreactor cultures, 6 was not the main GSL, i.e., the elicitor treated cultures showed the higher production of indole-type GSLs (Trp-derived).

In a study by Rubin et al. (2018), the amounts of two GSLs (6 and glucotropaeolin) had been investigated in $N$. officinale agar microshoot cultures grown with chitosan, casein hydrolysate, and coconut water as elicitors. In that study, the highest amount of $\mathbf{6}$ had been obtained in the C $(140.40 \mathrm{mg} / 100 \mathrm{~g} \mathrm{FW})$, while after treatment elicitors, the amount of $\mathbf{6}$ decreases with the maximum amount obtained for $0.5 \mathrm{~g} / \mathrm{L}$ casein hydrolysate $(68.00 \mathrm{mg} / 100 \mathrm{~g} \mathrm{FW})$. The influence of elicitors on the GSL content had also been the object of a study by Sánchez-Pujante et al. (2020) on Brassica oleracea L. var. italica suspension cell cultures. In their work, they had used coronatine $(0.5$ and $1 \mu \mathrm{M})$ and MeJA $(50$ and $100 \mu \mathrm{M})$. The cultures had been grown with the elicitors for $72 \mathrm{~h}$ and MeJA concentration of $50 \mu \mathrm{M}$ had been chosen as the best elicitor that boosted the production of GSLs by $B$. oleracea cells. In our study, over a similar duration of elicitation treatment ( $48 \mathrm{~h}$ and 4 days), we obtained promising results for $50 \mu \mathrm{M}$ MeJA, too (Supplementary Table S2). The work by Sánchez-Pujante et al. (2017) had also demonstrated a higher production of $\mathbf{8}$ in cells grown with $50 \mu \mathrm{M}$ MeJA in comparison with the control, which was also observed in our experiment (Table 3 ). In B. oleracea cells, MeJA had caused a higher production of $\mathbf{7}$ and 9 in comparison to the control cells. In our $N$. officinale microshoots, the amounts of these compounds after elicitation were lower than in $\mathrm{C}$ (Table 3).

The elicitation treatment influenced the total amount of flavonoids in our N. officinale microshoot cultures. The highest total flavonoid content was obtained for microshoot extracts collected after $24 \mathrm{~h}$ of treatment with $100 \mu \mathrm{M} \mathrm{NaSA}$, which was 1.1 times higher than in C. In the case of total polyphenol content determined by the $\mathrm{F}-\mathrm{C}$ method in the $N$. officinale microshoot cultures treated with elicitors, no stimulation of the production of that group of compounds was observed (Table 2 and Supplementary Table S2).

There have been numerous studies focused on the stimulation of the production of polyphenol compounds in different plant cultures in vitro with the use of different elicitors. For example, in the Phyllanthus pulcher callus cultures, SA had caused a higher increase in the production of polyphenols and flavonoids in comparison with MeJA (Danaee et al. 2015). The same effect was observed in our experiments for NaSA (Table 2 and Supplementary Table S2). In extracts from Salvia virgata shoot cultures, an increase had been obtained in the total phenolic and flavonoid accumulation after treatments with MeJA and YeE (Attaran Dowom et al. 2017). In the $N$. officinale microshoot cultures, this effect was observed only for the total flavonoids after treatment with MeJA. After elicitation with YeE, the total amount of polyphenols and flavonoids decreased in our study (Table 2 and Supplementary Table S2). Stimulation of the production of total flavonoids and total polyphenols has also been demonstrated for cell suspension cultures of Phoenix dactylifera (Al-Khayri and Naik 2020), Orostachys cartilaginous (Wen et al. 2019), and shoot cultures of Artemisia aucheri (Abbaspour and Ehsanpour, 2016) after treatment with SA as elicitor. In extracts from $B$. oleracea cell suspension cultures, the total amount of polyphenols also increased after elicitation with MeJA (Sánchez-Pujante et al. 2020).

The qualitative and quantitative analyses of polyphenol compounds using the HPLC method also confirmed the low influence of the elicitors on their amounts. In extracts from the elicitor-treated microshoots, the maximum amounts of $p$-coumaric acid and rutoside were respectively 1.7 and 1.2 
times lower than in C. Only the maximum amount of ferulic acid was 1.1 times higher after elicitation than in C (Table 4 and Supplementary Table S3). The qualitative and quantitative compositions of polyphenol compounds after treatments with elicitors have also been determined using the HPLC method in Centella asiatica shoot cultures (SkrzypczakPietraszek et al. 2019). That study had demonstrated different influences of the tested elicitors (MeJA and ETH), on the accumulation of phenolic compounds. The authors had claimed that different elicitors could have different effects on the production of individual phenolic compounds, which was confirmed also in our study (Table 4 and Supplementary Table S3). A study on Momordica dioica cell cultures had demonstrated that the elicitors SA and JA might not affect the production of some polyphenolic compounds (Chung et al. 2017). As in our study, higher amounts of $p$-coumaric acid had been found in C. On the other hand, SA and JA stimulated the production of ferulic acid (Table 4 and Supplementary Table S3).

The elicitation treatments applied in this study proved to also influence the amounts of soluble saccharides. The highest saccharide content was obtained for NaSA, which was 1.2 times higher than in C. An increase in the polysaccharide content caused by elicitation with SA has also been reported for $O$. cartilaginous cell cultures (Wen et al. 2019). On the other hand, an increase in soluble saccharides has also been demonstrated for A. aucheri shoot cultures treated with SA (Abbaspour and Ehsanpour 2016). Treatments with MeJA performed on B. oleracea var. botrytis grown in vivo have also been found to increase the soluble saccharide content (Sirhindi et al. 2020).

Under our study on $N$. officinale microshoot cultures, the stimulating effect of elicitation on chlorophyll production was evident after $24 \mathrm{~h}$ of treatment with $100 \mu \mathrm{M}$ NaSA (compared to C, 7.2 and 4.4 times increase in chlorophyll $a$ and $b$ content, respectively). Moreover, NaSA in both tested concentrations caused, over 6.0 times higher production of carotenoids after 8 days of treatment, in comparison with C (Table 5 and Supplementary Table S4). Similarly, higher amounts, in comparison with the control, for chlorophyll $a$ and $b$ content had been shown before for $P$. dactylifera and A. aucheri shoot cultures treated with SA (Abbaspour and Ehsanpour 2016; Al-Mayahi 2016). Additionally, higher accumulation of carotenoids after elicitation with SA had also been reported for A. aucheri cultures (Abbaspour and Ehsanpour 2016). The effect of higher production of carotenoids in in vitro cultures caused by elicitation with SA has also been demonstrated for $M$. dioica cell cultures (Chung et al. 2017). Moreover, the stimulating influence of elicitors (MeJA, chitosan, and $\mathrm{YeE}$ ) on the total carotenoid content has also been proved in Cleome rosea callus cultures (Silva da Rocha et al. 2015).
The influence of elicitation strategies on antioxidant potential assessed with the CUPRAC and FRAP methods showed that the maximum antioxidant activity was obtained after $24 \mathrm{~h}$ of treatment with $100 \mu \mathrm{M}$ MeJA, with the values being 1.8 and 2.1 times higher, respectively, than in C. This phenomenon has also been reported for $A$. aucheri shoot cultures treated with SA (Abbaspour and Ehsanpour 2016). With the DPPH assay, the maximum antioxidant activity was obtained after 6 days of elicitation with $50 \mu \mathrm{M} \mathrm{ETH}$, and the result was 2.2 times higher than in C (Table 6 and Supplementary Table S5). All the results for antioxidant capacity suggested a considerable influence of the flavonoid and polyphenol contents on this activity.

Under this study, we decided to check the possibility of using the analyzed extracts in the treatment of hypermelanosis. This is the first report confirming anti-melanin activities of $N$. officinale microshoot extracts. Our findings suggest potential usefulness of these extracts in treating dermatological hyperpigmentation problems. Anti-melanin activities had also been studied before for other elicitor-treated in vitro cultures such as $O$. cartilaginous bioreactor cultures elicited with $100 \mu \mathrm{M}$ SA over a 25 -day growth period and harvested after $48 \mathrm{~h}$ of treatment which showed the maximum inhibitory concentration for $1400 \mu \mathrm{g} / \mathrm{mL}$ (61.7\%) (Wen et al. 2019).

To sum up, our study has proven for the first time the impact of different elicitation strategies with $N$. officinale agitated microshoot cultures for the production of GSLs, flavonoids, polyphenols, saccharides, and photosynthetic pigments. Moreover, the antioxidant and anti-melanin activities of biomass extracts from these cultures were documented.

The experiments showed differences in the accumulation of GSLs and the stimulating effect of elicitation on the production of individual compounds-gluconasturtiin and glucobrassicin-which are precursors of isothiocyanates well known for their anticancer, antioxidant, and antibacterial properties. Moreover, the elicitors used increased the production of total flavonoids (100 $\mu \mathrm{M} \mathrm{NaSA})$, soluble saccharides (50 $\mu \mathrm{M} \mathrm{NaSA})$, and photosynthetic pigments (100 $\mu \mathrm{M}$ NaSA). The elicitation treatments did not adversely impact biomass growth; even $100 \mu \mathrm{M}$ MeJA and $50 \mu \mathrm{M}$ NaSA stimulated microshoot multiplication.

Furthermore, the experiments demonstrated increased antioxidant activity of $N$. officinale microshoot extracts after the applied elicitation treatments. Additionally, for the first time, biomass extracts from $N$. officinale microshoot cultures have been proved to inhibit tyrosinase activity.

Supplementary Information The online version contains supplementary material available at https://doi.org/10.1007/s00253-021-11743-8.

Author contribution Conceptualization, A.S., M.K.-S.; methodology, M.K.-S., A.S., M.D., I.B., A.Đ., A.A.; formal analysis, M.K.-S., A.S., M.D., I.B., A.Đ., A.A.; investigation, M.K.-S., A.S., M.D., I.B., 
A.Đ., A.A.; data curation, A.S., M.K.-S., M.D.; writing—original draft preparation, A.S., M.K.-S., H.E.; visualization, M.K.-S., A.S.; funding acquisition, M.K.-S., I.B.; critical revision of the manuscript: A.S., H.E., M.D., I.B., A.Đ.; contributed in writing and formatting the final version: M.K.-S., A.S., H.E., M.D., I.B., A.Đ., A.A. All authors participated in conducting experiments, writing, and approving the final manuscript. All authors have read and agreed to the published version of the manuscript.

Funding Financial support by the Croatian Science Foundation (Grant IP-2016-06-1316) is gratefully acknowledged by I.B as well as for the scientific-research equipment financed by EU grant "Functional integration of the University of Split, PMF-ST, PFST and KTFST through the development of the scientific and research infrastructure." The research was realized as a part of the research project supported by the Polish Ministry of Science and Higher Education (Grant PL: N/42/DBS/000122), and the Croatian Science Foundation (Grant IP-2016-06-1316). The funders had no role in the design of the study; in the collection, analyses, or interpretation of data; in the writing of the manuscript, or in the decision to publish the results.

Data availability Raw data were generated at the Chair and Department of Pharmaceutical Botany, Faculty of Pharmacy, Jagiellonian University, Medical College. Derived data supporting the findings of this study are available from the corresponding author on request.

\section{Declarations}

Ethics approval This article does not contain any studies with human participants or animals performed by any of the authors.

Conflict of interest The authors declare no competing interests.

Open Access This article is licensed under a Creative Commons Attribution 4.0 International License, which permits use, sharing, adaptation, distribution and reproduction in any medium or format, as long as you give appropriate credit to the original author(s) and the source, provide a link to the Creative Commons licence, and indicate if changes were made. The images or other third party material in this article are included in the article's Creative Commons licence, unless indicated otherwise in a credit line to the material. If material is not included in the article's Creative Commons licence and your intended use is not permitted by statutory regulation or exceeds the permitted use, you will need to obtain permission directly from the copyright holder. To view a copy of this licence, visit http://creativecommons.org/licenses/by/4.0/.

\section{References}

Abbaspour J, Ehsanpour A (2016) The impact of salicylic acid on some physiological responses of Artemisia aucheri Boiss. under in vitro drought stress. Acta Agric Slov 107:287-298 . https://doi.org/10. 14720/aas.2016.107.2.03

Afsharypuor S, Salehi M (2008) Volatile constituents of leaves and stems of Nasturtium officinale R. Br J Essent Oil Res 20:517-518. https://doi.org/10.1080/10412905.2008.9700076

Al-Khayri JM, Naik PM (2020) Elicitor-induced production of biomass and pharmaceutical phenolic compounds in cell suspension culture of date palm (Phoenix dactylifera L.). Molecules 25(20):4669. https://doi.org/10.3390/molecules25204669
Al-Mayahi AMW (2016) Influence of salicylic acid (SA) and ascorbic acid (ASA) on in vitro propagation and salt tolerance of date palm (Phoenix dactylifera L.) cv. "Nersy.” Aust J Crop Sci 10:969-976 . https://doi.org/10.21475/ajcs.2016.10.07.p7640

Attaran Dowom S, Abrishamchi P, Radjabian T, Salami SA (2017) Enhanced phenolic acids production in regenerated shoot cultures of Salvia virgata Jacq. after elicitation with $\mathrm{Ag}^{+}$ions, methyl jasmonate and yeast extract. Ind Crops Prod 103:81-88. https://doi. org/10.1016/j.indcrop.2017.03.043

Bach A, Kapczyńska A, Dziurka K, Dziurka M (2015) Phenolic compounds and carbohydrates in relation to bulb formation in Lachenalia "Ronina" and "Rupert" in vitro cultures under different lighting environments. Sci Hortic (Amsterdam) 188:2329. https://doi.org/10.1016/j.scienta.2015.02.038

Bahramikia S, Yazdanparast R (2010) Antioxidant efficacy of Nasturtium officinale extracts using various in vitro assay systems. JAMS J Acupunct Meridian Stud 3:283-290. https://doi. org/10.1016/S2005-2901(10)60049-0

Barba-Espín G, Chen ST, Agnolet S, Hegelund JN, Stanstrup J, Christensen JH, Müller R, Lütken H (2020) Ethephon-induced changes in antioxidants and phenolic compounds in anthocyanin-producing black carrot hairy root cultures. J Exp Bot 71:7030-7045. https://doi.org/10.1093/jxb/eraa376

Benzie IFF, Strain JJ (1996) The ferric reducing ability of plasma (FRAP) as a measuer of "antioxidant power": the FRAP assay. Anal Biochem 239:70-76

Biesaga-Kościelniak J, Dziurka M, Ostrowska A, Mirek M, Kościelniak J, Janeczko A (2014) Brassinosteroid improves content of antioxidants in seeds of selected leguminous plants. Aust J Crop Sci 8:378-388

Blažević I, Đulović A, Čikeš Čulić V, Burčul F, Ljubenkov I, Ruščić M, Generalić Mekinić I (2019) Bunias erucago L.: glucosinolate profile and in vitro biological potential. Molecules 24:111. https://doi.org/10.3390/molecules 24040741

Blios MS (1958) Antioxidant determinations by the use of a stable free radical. Nature 26:1199-1200

Boligon AA, Janovik V, Boligon AA, Pivetta CR, Pereira RP, Da RJBT, Athayde ML (2013) HPLC analysis of polyphenolic compounds and antioxidant activity in Nasturtium officinale. Int J Food Prop 16:61-69. https://doi.org/10.1080/10942912. 2010.528111

Brown PD, Tokuhisa JG, Reichelt M, Gershenzon J (2003) Variation of glucosinolate accumulation among different organs and developmental stages of Arabidopsis thaliana. Phytochemistry 62:471-481. https://doi.org/10.1016/S0031-9422(02)00549-6

Chien CC, Tsai ML, Chen CC, Chang SJ, Tseng CH (2008) Effects on tyrosinase activity by the extracts of Ganoderma lucidum and related mushrooms. Mycopathologia 166:117-120. https://doi. org/10.1007/s11046-008-9128-x

Chodisetti B, Rao K, Gandi S, Giri A (2015) Gymnemic acid enhancement in the suspension cultures of Gymnema sylvestre by using the signaling molecules-methyl jasmonate and salicylic acid. Vitr Cell Dev Biol - Plant 51:88-92. https://doi.org/10.1007/ s11627-014-9655-8

Chung IM, Rekha K, Rajakumar G, Thiruvengadam M (2017) Jasmonic and salicylic acids enhanced phytochemical production and biological activities in cell suspension cultures of spine gourd (Momordica dioica Roxb). Acta Biol Hung 68:88-100. https:// doi.org/10.1556/018.68.2017.1.8

Czyczyło-Mysza I, Tyrka M, Marcińska I, Skrzypek E, Karbarz M, Dziurka M, Hura T, Dziurka K, Quarrie SA (2013) Quantitative trait loci for leaf chlorophyll fluorescence parameters, chlorophyll and carotenoid contents in relation to biomass and yield in bread wheat and their chromosome deletion bin assignments. Mol Breed 32:189-210. https://doi.org/10.1007/s11032-013-9862-8 
Danaee M, Farzinebrahimi R, Kadir MA, Sinniah UR, Mohamad R, Mat Taha R (2015) Effects of MeJA and SA elicitation on secondary metabolic activity, antioxidant content and callogenesis in Phyllanthus pulcher. Rev Bras Bot 38:265-272. https://doi.org/ 10.1007/s40415-015-0140-3

De Lira RM, De Franca E Silva EF, Da Silva AO, De Medeiros PRF, Da Silva GF, Soares HRE (2019) Watercress and chinese cabbage in a hydroponic system using groundwater. Rev Caatinga 32:1038-1047. https://doi.org/10.1590/1983-21252019v32n420rc

De Souza DA, Costa PM, Ribeiro RIMA, Vidigal PVT, Pinto FCH (2016) Daily intake of watercress causes inhibition of experimental Ehrlich tumor growth. J Bras Patol e Med Lab 52:393-399. https://doi.org/10.5935/1676-2444.20160063

Dong J, Wan G, Liang Z (2010) Accumulation of salicylic acid-induced phenolic compounds and raised activities of secondary metabolic and antioxidative enzymes in Salvia miltiorrhiza cell culture. J Biotechnol 148:99-104. https://doi.org/10.1016/j.jbiotec.2010. 05.009

Dubois M, Gilles K, Hamilton JK, Rebers PA, Smith F (1951) A colorimetric method for the determination of sugars. Nature 168:167-168

EFSA European Food Safety Authority (EFSA). http://www.efsa. europa.eu/. Accessed 25 Jan 2021

Ellnain-Wojtaszek M, Zgórka G (1999) High-performance liquid chromatography and thin-layer chromatography of phenolic acids from Gingko biloba L. leaves collected within vegetative period. J Liq Chromatogr Relat Technol 22:1457-1471. https://doi.org/10. 1081/JLC-100101744

Gallaher CM, Gallaher DD, Peterson S (2012) Development and validation of a spectrophotometric method for quantification of total glucosinolates in cruciferous vegetables. J Agric Food Chem 60:1358-1362. https://doi.org/10.1021/jf2041142

Grosser K, van Dam NM (2017) A straightforward method for glucosinolate extraction and analysis with high-pressure liquid chromatography (HPLC). J vis Exp 2017:1-9. https://doi.org/10.3791/ 55425

Grzegorczyk I, Wysokińska H (2008) Liquid shoot culture of Salvia officinalis L. for micropropagation and production of antioxidant compounds; effects of triacontanol. Acta Soc Bot Pol 77:99-104. https://doi.org/10.5586/asbp.2008.013

Holst B, Williamson G (2004) A critical review of the bioavailability of glucosinolates and related compounds. Nat Prod Rep 21:425-447. https://doi.org/10.1039/b204039p

Jeon J, Bong SJ, Park JS, Park YK, Arasu MV, Al-Dhabi NA, Park SU (2017) De novo transcriptome analysis and glucosinolate profiling in watercress (Nasturtium officinale $\mathrm{R}$. Br.). BMC Genomics 18:1-14. https://doi.org/10.1186/s12864-017-3792-5

Karuppusamy S (2009) A review on trends in production of secondary metabolites from higher plants by in vitro tissue, organ and cell cultures. J Med Plants Res 3:1222-1239

Klimek-Szczykutowicz M, Dziurka M, Blažević I, Đulović A, Granica S, Korona-Glowniak I, Ekiert H, Szopa A (2020a) Phytochemical and biological activity studies on Nasturtium officinale (watercress) microshoot cultures grown in RITA ${ }^{\circledR}$ temporary immersion systems. Molecules 25(22):5257. https://doi.org/10.3390/molec ules 25225257

Klimek-Szczykutowicz M, Szopa A, Blicharska E, Dziurka M, Komsta $€$, Ekiert H (2019) Bioaccumulation of selected macro- and microelements and their impact on antioxidant properties and accumulation of glucosinolates and phenolic acids in in vitro cultures of Nasturtium officinale (watercress) microshoots. Food Chem 300:125184. https://doi.org/10.1016/j.foodchem.2019. 125184

Klimek-Szczykutowicz M, Szopa A, Dziurka M, Komsta $Ł$, Tomczyk M, Ekiert H (2020) The influence of Nasturtium officinale $\mathrm{R} \mathrm{Br}$ agar and agitated microshoot culture media on glucosinolate and phenolic acid production, and antioxidant activity. Biomolecules 10:1216. https://doi.org/10.3390/biom10091216

Krzyzanowska J, Czubacka A, Pecio L, Przybys M, Doroszewska T, Stochmal A, Oleszek W (2012) The effects of jasmonic acid and methyl jasmonate on rosmarinic acid production in Mentha $\times$ piperita cell suspension cultures. Plant Cell Tissue Organ Cult 108:73-81. https://doi.org/10.1007/s11240-011-0014-8

Li Q, Zhan M, Chen W, Zhao B, Yang K, Yang J, Yi J, Huang Q, Mohan M, Hou Z, Wang J (2016) Phenylethyl isothiocyanate reverses cisplatin resistance in biliary tract cancer cells via glutathionylation-dependent degradation of Mcl-1. Oncotarget 7:10271-10282 . https://doi.org/10.18632/oncotarget.7171

Lira RM, Silva ÊFF, Silva GF, Soares HR, Willadino LG (2018) Growth, water consumption and mineral composition of watercress under hydroponic system with brackish water. Hortic Bras 36:13-19. https://doi.org/10.1590/s0102-053620180103

Martínez-Sánchez A, Gil-Izquierdo A, Gil MI, Ferreres F (2008) A comparative study of flavonoid compounds, vitamin C, and antioxidant properties of baby leaf Brassicaceae species. J Agric Food Chem 56:2330-2340. https://doi.org/10.1021/jf072975+

Murashige T, Skoog F (1962) A revised medium for rapid growth and bioassays with tobacco tissue cultures. Physiol Plant 15:473-497

Narayani M, Srivastava S (2017) Elicitation: a stimulation of stress in in vitro plant cell/tissue cultures for enhancement of secondary metabolite production. Phytochem Rev 16:1227-1252. https://doi. org/10.1007/s11101-017-9534-0

Özyürek M, Güçlü K, Bektaşoğlu B, Apak R (2007) Spectrophotometric determination of ascorbic acid by the modified CUPRAC method with extractive separation of flavonoids-La(III) complexes. Anal Chim Acta 588:88-95. https://doi.org/10.1016/j. aca.2007.01.078

Palaniswamy UR, McAvoy RJ (2001) Watercress: a salad crop with chemopreventive potential. Horttechnology 11:622-626. https:// doi.org/10.21273/horttech.11.4.622

Peltonen S, Mannonen L, Karjalainen R (1997) Elicitor-induced changes of phenylalanine ammonia-lyase activity in barley cell suspension cultures. Plant Cell Tissue Organ Cult 50:185-193. https://doi.org/10.1023/A:1005908732706

Ramos RTM, Bezerra ICF, Ferreira MRA, Soares LAL (2017) Spectrophotometric quantification of flavonoids in herbal material, crude extract, and fractions from leaves of Eugenia uniflora Linn. Pharmacognosy Res 9:253-260. https://doi.org/10.4103/pr.pr_143_16

Rao UMV, Gaviraj EN, Veeresham C (2010) Effect of ethephon and ancymidol on the production of hypericins in shoot cultures of Hypericum perforatum. Indian Drugs 47:77-79

Rubin E, Aziz ZA, Surugau N (2018) Glucosinolates content in nonelicited plant culture, elicited plant culture and wild plant of watercress (Nasturtium officinale). Trans Sci Tech 5:40-45

Sadeghi H, Mostafazadeh M, Sadeghi H, Naderian M, Barmak MJ, Talebianpoor MS, Mehraban F (2014) In vivo anti-inflammatory properties of aerial parts of Nasturtium officinale. Pharm Biol 52:169-174. https://doi.org/10.3109/13880209.2013.821138

Sánchez-Pujante PJ, Borja-Martínez M, Pedreño MÁ, Almagro L (2017) Biosynthesis and bioactivity of glucosinolates and their production in plant in vitro cultures. Planta 246:19-32. https:// doi.org/10.1007/s00425-017-2705-9

Sánchez-Pujante PJ, Gionfriddo M, Sabater-Jara AB, Almagro L, Pedreño MA, Diaz-Vivancos P (2020) Enhanced bioactive compound production in broccoli cells due to coronatine and methyl jasmonate is linked to antioxidative metabolism. J Plant Physiol 248:153136. https://doi.org/10.1016/j.jplph.2020.153136

Santamaria AR, Innocenti M, Mulinacci N, Melani F, Valletta A, Sciandra I, Pasqua G (2012) Enhancement of viniferin production in Vitis vinifera L. cv. Alphonse Lavallée cell suspensions 
by low-energy ultrasound alone and in combination with methyl jasmonate. J Agric Food Chem 60:11135-11142. https://doi.org/ 10.1021/jf301936u

Silva da Rocha A, Rocha EK, Alves LM, Amaral de Moraes B, Carvalho de Castro T, Albarello N, Simões-Gurgel C (2015) Production and optimization through elicitation of carotenoid pigments in the in vitro cultures of Cleome rosea Vahl (Cleomaceae). J Plant Biochem Biotechnol 24:105-113. https://doi.org/10.1007/ s13562-013-0241-7

Singleton VL, Orthofer R, Lamuela-Raventos RM (1999) Analysis of total phenols and other oxidation substrates and antioxidants by means of Folin-Ciocalteu reagent. Methods Enzym 299:152-178. https://doi.org/10.1016/S0076-6879(99)99017-1

Sirhindi G, Kaushik S, Mushtaq R, Sharma P, Dogra N (2020) Jasmonates induce growth and modulation in pigments and vitamins of Brassica oleracea var. capitata, italica and botrytis edible heads (foliage/inflorescence). Rev Bras Bot 43:705-719. https:// doi.org/10.1007/s40415-020-00652-1

Skrzypczak-Pietraszek E, Urbańska A, Żmudzki P, Pietraszek J (2019) Elicitation with methyl jasmonate combined with cultivation in the Plantform ${ }^{\mathrm{TM}}$ temporary immersion bioreactor highly increases the accumulation of selected centellosides and phenolics in Centella asiatica (L.) Urban shoot culture. Eng Life Sci 19:931-943. https://doi.org/10.1002/elsc.201900051

Sułkowska-Ziaja K, Grabowska K, Apola A, Kryczyk-Poprawa A, Muszyńska B (2021) Mycelial culture extracts of selected wood-decay mushrooms as a source of skin-protecting factors. Biotechnol Lett 43:1051-1061. https://doi.org/10.1007/ s10529-021-03095-0

Sułkowska-Ziaja K, Maślanka A, Szewczyk A, Muszyńska B (2017) Physiologically active compounds in four species of genus Phellinus. Nat Prod Commun 12:363-366. https://doi.org/10.1177/ 1934578 X1701200313

Szopa A, Kokotkiewicz A, Król A, Luczkiewicz M, Ekiert H (2018) Improved production of dibenzocyclooctadiene lignans in the elicited microshoot cultures of Schisandra chinensis (Chinese magnolia vine). Appl Microbiol Biotechnol 102:945-959. https://doi. org/10.1007/s00253-017-8640-7
Thanh NT, Murthy HN, Yu KW, Hahn EJ, Paek KY (2005) Methyl jasmonate elicitation enhanced synthesis of ginsenoside by cell suspension cultures of Panax ginseng in 5-1 balloon type bubble bioreactors. Appl Microbiol Biotechnol 67:197-201. https://doi. org/10.1007/s00253-004-1759-3

Wathelet JP, Iori R, Leoni O, Quinsac O, Palmieri S (2004) Guidelines for glucosinolate analysis in green tissues used for biofumigation. Agroindustria 3:257-266

Wen T, Hao YJ, An XL, Sun HD, Li YR, Chen X, Piao XC, Lian ML (2019) Improvement of bioactive compound accumulation in cell cultures of Orostachys cartilaginous A. Bor. through elicitation with salicylic acid and effect of cell extract on bioactive activity. Ind Crops Prod 139:111570 . https://doi.org/10.1016/j.indcrop. 2019.111570

Wiktorowska E, Długosz M, Janiszowska W (2010) Significant enhancement of oleanolic and accumulation by biotic elicitors in cell suspension cultures of Calendula officinalis L. Enzyme Microb Technol 46:14-20

Yu ZZ, Fu CX, Han YS, Li YX, Zhao DX (2006) Salicylic acid enhances jaceosidin and syringin production in cell cultures of Saussurea medusa. Biotechnol Lett 28:1027-1031. https://doi.org/ 10.1007/s10529-006-9035-5

Yuan J-M, Stepanov I, Murphy SE, Wang R, Allen S, Jensen J, Strayer L, Adams-Haduch J, Upadhyaya P, Le C, Kurzer MS, Nelson HH, Yu MC, Hatsukami D, Hecht SS (2016) Clinical trial of 2-phenethyl isothiocyanate as an inhibitor of metabolic activation of a tobacco-specific lung carcinogen in cigarette smokers. Cancer Prev Res 9:396-405. https://doi.org/10.1158/1940-6207.CAPR15-0380.Clinical

Publisher's note Springer Nature remains neutral with regard to jurisdictional claims in published maps and institutional affiliations. 